https://doi.org/10.48009/2_iis_2006_354-358

\title{
THE EFFECT OF KNOWLEDGE MANAGEMENT CAPABILITY ON THE IC DESIGN INDUSTRY IN TAIWAN
}

\author{
Chu-Yi Hsu, National Taitung University, yie@nttu.edu.tw \\ Edward T. Chen, University of Massachusetts Lowell, edward_chen@uml.edu \\ Kuoching Feng, National Taitung University, feng@nttu.edu.tw
}

\begin{abstract}
In the emerging knowledge-based economy, knowledge management capability reflects the strategic management of intellectual assets. The integrated circuit design (IC) industry is an assetlight but knowledge-intensive one with a series of value-added activities. This study investigated how the IC design companies in Taiwan utilized KM to improve new product development. Based on data collected from the IC design field, results from path analysis indicated that the human process capital had a positive effect on new product development while the KM capability had a positive effect on the human process capital. The empirical findings certainly help both the researchers and practitioners in the future $K M$ research in the IC field.
\end{abstract}

Keywords: Knowledge Management, Intellectual Capital, New Product Development, IC Design

\section{INTRODUCTION}

Instead of using more capital, labor, and materials to guarantee the success of common business, knowledge has become the foundation for long lasting competition between enterprises. The key factor leading to success has been transformed from capital management to knowledge management. A long lasting cooperation will invest in new information technology to gain sustainability. To survive and search for effective management in a highly competitive environment, continuously investing in new technologies and launching new products are inevitable for IC design firms. With the nature of asset-light, knowledge intensive and high added value, the management of knowledge and intellectual assets is becoming important in the industry of IC design. This research used Taiwan ICdesign enterprises as a research base to study the impact of knowledge management ability on the development of new product.

\section{New Product Development}

Grant [5] proposed that production development is an ability to coordinate cross-level functions of an organization. It involves a broader scope of knowledge integration and whether knowledge control directives can be effective for new product development so much as to influence new product development. Cooper and Kleinschmidt [2] proposed a measure for the performance of product innovation, which consists of three aspects: financial performance, influence of markets, and window of chance. Larson and Gobeli [10] used four indices which are the product innovation and project achievement rate, project cost control, the project technique satisfaction degree, and the performance satisfaction degree of the whole project.

Song and Parry [15] suggested that among the factors that contribute to the success of new product development, knowledge integration plays a very important role. They also suggested five measure indices: the integration of development manufacturing and marketing, information sharing, the company resources of marketing and technologies, new product design (NPD) activity proficiency, and market characteristics. Bayus, Erickson, and Jacobson [1] found that new product introductions influenced profit rate and size; however, they found no effect on profit-rate persistence. Interestingly, they also found that the effect of new product introductions on profit rate stemmed from a reduction in selling and general administrative expenditure intensity rather than through an increase in gross operating return.

Nortel implements a KM tool, called Virtual Mentor, designed as an electronic performance support system. The KM processes allowed Nortel to efficiently leverage multi-disciplinary knowledge assets in the front-end process of NPD, improve NPD decision-making processes, and facilitate organizational learning and knowledge transfer [12]. In a nutshell, the definition of new product can be divided into original products, improved products, modified products, and new brands. New product innovation can be compartmentalized as product innovation, process innovation, and service innovation. 


\section{The Measurement of Intellectual Capital}

Per Ross et al. [13, 14], intellectual capital is developed from knowledge management. The enterprise intellectual capital is the total of its employees. The capitals of a company are categorized into financial capital and intellectual capital. Intellectual capital is further divided into human capital and structural capital, and characterized as with or without thought. According to their use inside or outside the company, structural capital is classified into the relationship capital, organizational capital and "innovation and development" capital. Edvinsson [4] suggested that intellectual capital of a company is its proficiency and expertise of knowledge, experiences, organizational technologies and customer relationship and specialized skills. $\mathrm{He}$ also categorizes intellectual capital into human capital and structural capital. Furthermore structural capital is divided into customer capital and organizational capital by its use internally or externally. Analogously, organizational capital is divided into innovation capital and process capital. Edvinsson [4] emphasized the importance of the interaction of various intellectual capital elements, and through the interaction, the elements can create new values.

Johnson [7] proposed that intellectual capital consists of human capital, innovation capital, process capital, and relationship capital. He identified human capital as employees with knowledge, employees' talents and attitudes and the characteristics of the managers. Innovation capital consists of intellectual assets such as patents, copyrights, logos, and databases. Process capital consists of work flows, trading, and operational secrets while relationship capital includes its interactions between customers, suppliers, and network users.

Van Buren's [16] idea of intellectual capital is as follows: human capital consists of the knowledge, skills, and experiences of the members of the organization. Structural capital includes the use of IT, the company's reputation, databases, patents, copyrights, systems, tools, and operational philosophy. Innovation capital consists of the innovation ability of the organization, and the innovation fruition. Process capital includes organization work flows and technique design flow. Customer capital is the organizations' interaction with its customers.

\section{RESEARCH METHODOLOGY}

This study was an exploratory research evaluating the capability of knowledge management. The questionnaires were designed by using the measurement indices of intellectual capital to investigate the effect of knowledge management capability on new product development. The samples were taken from the top ten IC design corporations in Taiwan from 2001 to 2003. Questionnaire surveys and expert interview were conducted simultaneously. The results from data analyses were used to verify our hypotheses. These findings were also compared with the results from expert interviews to further validate our propositions.

\section{Research Model}

Song and Parry [15] indicated that among the factors that contribute to the success of a new product development, knowledge integration play a very important role. Madhavan and Grover [11] pointed out that a new product development was the manifestation of knowledge creation, which transformed tacit knowledge to explicit knowledgealso called knowledge materialization. Greengard [6] proposed that the development of techniques and new products was the accumulation of knowledge and intelligence; hence the management of intellectual assets had important influence on new product development.

The balance scorecard proposed by Kaplan and Norton [8,9] also emphasized the casual relationship in four dimensions because different strategies in an enterprise would affect the measurement indices in these dimensions. Wang and Chang [17] revealed that intellectual capital elements interacted with each other to make a contribution. If the causation can be understood and the leading factor can be supervised, the enterprise intellectual capital will be improved. The capability of knowledge management in a corporation is composed by four factors: human, consumer, intellectual property management, and process capital. These mutually dependent factors have direct impact on the efficiency of new product development.

\section{Research Hypothesis}

According to Wang and Chang [17], the key factors on intellectual capital have mutual impacts on each other. In this research, Hypotheses 5 to 10 addressed the associations between knowledge management capability and new product development. Moreover, Hypotheses 1 to 4 and Hypothesis 11 were 
conjectured according to the case using knowledge management to shorten the cycle of developing new products [3].

H1: The capability of knowledge management on consumer capital has a positive impact on developing new products.

H2: The ability of intellectual property management has a positive impact on the development of new products.

H3: The capability of knowledge management on human capital has positive impact on developing new products.

H4: The capability of knowledge management on process capital has a positive impact on developing new products.

H5: Human capital has a positive impact on the management of intellectual property in the factor of knowledge management.

H6: Human capital has a positive impact on process capital in the factor of knowledge management.

H7: Human capital has a positive impact on consumer capital in the factor of knowledge management.

H8: The capability of intellectual asset management has a positive impact on consumer capital in the factor of knowledge management.

H9: The capability of intellectual asset management has a positive impact on process capital in the factor of knowledge management.

H10: The process capital has a positive impact on consumer capital in the factor of knowledge management.

H11: The ability to predict new products has a positive impact on the cycle of development.

\section{Process of Questionnaire Design}

The structural questionnaire design approach was applied to develop the survey instrument. The level of importance was measured using a five-point Likert scale. In the questionnaire design process, the first stage was to search for a model based on previous research. The second stage was to modify the questionnaire design by referencing previous related designs. To increase the aptness and reliability of the questionnaire, experts were invited to review the questionnaire and pilot tests were administered. The target groups were the managers of strategy management units, knowledge management departments, and R\&D departments of Taiwan's top 10 IC design companies from 2001 to 2003. To increase the return rate, each company was assigned a contact person to collect and return the questionnaires via e-mail.

\section{DATA ANALYSIS AND RESULTS}

In this study, 250 questionnaires were mailed and 115 questionnaires were received; 113 had complete responses. The effective return rate was about $45.2 \%$. In these 113 valid samples, 97 respondents were males $(85.8 \%)$ and 16 were females $(14.2 \%)$. Of those 113 respondents, 56 were less than 30 years old $(49.6 \%)$ and 56 were between 30 to 40 years old (49.6\%). Among them, 1 had Ph.D. degree (0.9\%), 74 had master degrees (65.5\%), 35 had bachelor degree $(31 \%)$ and 3 had junior college degrees $(2.6 \%)$. Among these, those with master's degrees had the highest proportion.

Graduate training usually assists employee's profession learning and problem solving capability. It will also improve the efficiency of enterprise's internal business functions. Grouping the subjects by job department, there were 67 in the $R \& D$ department, 21 in the engineering department, 13 in the product development department, 1 in the knowledge management department, and 13 in other functional departments. The lengths of career of these subjects were as follows: 48 were working less than 2 years; 47 were from 2 to 5 years. There were $84 \%$ with the service length less than 6 years.

\section{Stability, Reliability, and Validity}

To test the temporal stability, the collected questionnaires were divided into two groups based on their return dates. The numbers of samples in the two groups were 58 and 55. Their P-values were both greater than the 0.05 significance level, which showed consistency of the two sample groups. Exploratory factor analysis was adopted to test construct validity. Cronbach's alpha was calculated to examine the reliability of each individual item. Every Alpha coefficient was above 0.9 and indicates high reliability of each individual item.

Factor analysis was conducted both on knowledge management construct and new product development construct. In the knowledge management capability dimension, only factor loadings higher than 0.55 
were chosen to represent the factor. The accumulated variance explained by these chosen items was 68.687 and the Cronbach's $\alpha$ was 0.9635 . The accumulated variances explained by these items of new product development dimension was 69.267 and the Cronbach's $\alpha$ was 0.9557 . The $Z$ value of the skewness and kurtosis in Normality test indicated that samples were normally distributed. From the result of Pearson's correlation coefficient, there was no multicollinearity between variables.

\section{CONCLUSIONS}

We verified the hypotheses of the effect of knowledge management capability on the efficiency of new product development. The relation between the capability of knowledge management and the efficiency of new product development was confirmed in this study. The findings are summarized as follows: (1) Human capital and process capital had a positive impact on the ability of predicting new products, the cycle of product development, and information sharing. (2) Human capital had a positive impact on process capital, consumer capital, and the capability of knowledge management. (3) The capability of intellectual property management had a positive impact on process capital. (4) Consumer capital had a positive impact on predicting new products. (5) The ability of predicting new product had a positive impact on the cycle of developing new products. (6) The management of intellectual property and information sharing were not currently well processed in the IC design firms. These results were further confirmed through expert interviews.

In the knowledge management capability construct, the path coefficients of the human capital module were listed in descending order to show the importance of each factor as follows: new product development capacity, product innovation competitiveness, knowledge sharing, staff's professional ability, enterprises-attraction and encouragement-talents, staff's centripetal force. The path coefficients of the customer human capital module were listed in descending order to show the importance of the following factors: orientation of customer and customer satisfaction. The path coefficients of the process capital module were listed in descending order as follows: control of the procedure operation flow, the procedure control ability of knowledge management, organizing the culture, and complete structure of information system. Managers can build up their firm's knowledge management capability by checking the above-mentioned factors according to their strategic importance.
In the new product development performance construct, the path coefficients of the new product prediction module were listed in descending order as follows: the enterprise planning ability of new products, company's resource of marketing and technology, market survey capability, and new product satisfaction. The path coefficients of the new product development cycle module were listed in descending order as follows: the new product development technology, product innovation degree, project completion rate, and product development success rate to market. Managers can extrapolate the implications of new product development from this priority list. This specialization will help managers gain competitive advantage by understanding how to identify each factor to enhance organizational productivity and new product development.

Key findings on the ability of knowledge management in this study include the following: (1) Human capital can promote process capital through improving intellectual property management. (2) Human capital can improve the efficiency of new product development through enhancing the process capital and increase the ability on predicting new products through consumer capitals. (3) Human capital is the fundamental factor in the construction of intellectual property. The knowledge and ability of employees are the origin of innovations. The accumulation of innovation capital and intellectual property management depend not only on the investigation of enterprise, but also on the incubation and the growth of invention from the employees. Therefore, human capital, innovation capital, and intellectual property management are interrelated.

Employees deliver the service quality to consumers by a tunneling process or direct contact. It is clear that human capital has impact on process capital and consumer capital. Excellent R\&D ability can simplify the new product development cycle. Innovation capital and intellectual asset management can support and promote the process capital. Therefore, knowledge management capability has considerable appeal to high-tech firms, especially in the IC design industry, as a strategy to improve organizational productivity and new product development.

\section{REFERENCES}

1. Bayus, B.L., Erickson G., \& Jacobson R. (2003). The financial rewards of new product introductions in the personal computer industry. Management Science, 49(2), 197-210.

2. Cooper, R.G. \& Kleinschmidt, E.J. (1987). What makes a new product a winner: Success factors 
at the project level? $R \& D$. Management, 17(3), 175-189.

3. Davenport, T. H., \& Prusak, L. (1998). Working knowledge: How organizations manage what they know. Cambridge, MA: Harvard Business School Press.

4. Edvinsson, L. \& Malone, S. (1997). Intellectual capital: realizing your company's true value by finding its hidden brainpower, New York: Harper Business Publishers, Inc.

5. Grant, R.M. (1996). Toward a knowledge-based theory of the firm. Strategic Management Journal, 17(1), 109-122.

6. Greengard, S. (1998). How to make KM a reality. Work Force, 77(10), 90-91.

7. Johnson, W.H. (1999). An integrative taxonomy of intellectual capital: Measuring the stock and flow of intellectual capital components in the firm. International Journal of Technology Management, 18(5/6/7/8), 562-575.

8. Kaplan, R.S. \& Norton, D.P. (2001). The strategy-focused organization, Boston: Harvard Business School Press.

9. Kaplan, S. (2002). KM the right way: A step-bystep approach that will ensure your expensive KM system actually gets used. CIO, 15(19), 7481.

10. Larson, E.W. \& Gobeli, D.H. (1988). Organizing for product development projects. The Journal of Product Innovation Management, 5(3), 180-190.

11. Madhavan, R. \& Grover, R. (1998). From embedded knowledge to embodied knowledge: new product development as knowledge management. Journal of Marketing, 62(4), 1-12.

12. Massey, A.P. (2002). Knowledge management in pursuit of performance: insight from Nortel Networks. MIS Quarterly, 26(3), 269-289.

13. Ross, G. \& Ross, J. (1997). Measuring your company's intellectual performance. Long Range Planning, 30(3), 413-426.

14. Ross, J., Ross G., Edvinsson L., \& Dragonetti, N.C. (1998). Intellectual capital: navigating in the new business landscape, New York: New York University Press.

15. Song, X.M. \& Parry, M.E. (1997). A crossnational comparative study of new product development processes: Japan and the United States. Journal of Marketing, 61(2), 1-18.

16. Van Buren, M.E. (1999). A yardstick for knowledge management. Training \& Development, 53(5), 71-78.

17. Wang, W.Y. \& Chang, C.F. (2005). Intellectual capital and performance: an empirical investigation of the Taiwan semiconductor industry. Journal of Intellectual Capital, 6(2), 222-236. 